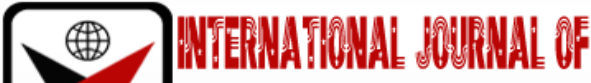

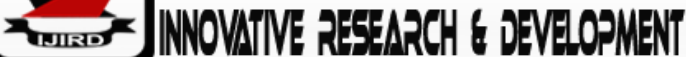

ISSN 2278-0211 (Online)

\section{Potentials and Viabilities of Abandoned Public Buildings in Nigeria}

Ifeoluwa Akande
Lecturer, Department of Architecture,
Bells University of Technology, Ota, Ogun State Nigeria
Damilare Sowemimo
Lecturer, Department of Architecture,
Bells University of Technology, Ota, Ogun State Nigeria
Olabode Oyedele
Lecturer, Department of Architecture,
Bells University of Technology, Ota, Ogun State Nigeria
Abideen Abass
Assistant Lecturer, Department of Architecture
Bells University of Technology, Ota, Ogun State Nigeria

\begin{abstract}
:
Public buildings are built with substantial amount of money. Incessant abandonment of these facilities undoubtedly comes with negative impacts. The most significant of such buildings is the Old Federal Secretariat located in Ikoyi, Lagos. The aim of this study is to examine the potentials and viabilities of abandoned government buildings using the said facility. The study adopts a combination of literature review, site visitation and quantitative approach using Linkert scale structured questionnaire. Study samples were drawn from the residents of the environment. A total of 300 questionnaires were administered using systematic random sampling technique in selecting study respondents. Findings shows that there is a decrease in the tempo of economic activities, increase in vandalism and crime rate, devaluation impact on adjoining properties; increase in incidence of blight environment and menace to the environment aesthetics with overall negative impact on the abandoned building. During this research, it became evident that institutional technicalities keep lingering to put the building into adaptive reuse. The study however recommends that stakeholders be educated on the benefit of adaptive reuse of public buildings: a workable model that would be geared towards revamping abandoned public facilities should be created. Lastly, the existing land use characteristics within such area should be considered to ensure that the new use is compatible with the prevailing land use.
\end{abstract}

Keywords: Abandonment, adaptive, building, environment, viability

\section{Introduction}

There is prevalence of abandoned buildings in both developed and developing countries. Madison (20170 noted that there are many cities all across the world littered with abandoned buildings and structures. Hence, building abandonment is not peculiar to Nigeria. Lagos was designated as Nigeria's capital city in 1914; however, Nigeria moved her capital from Lagos to Abuja in 1991. The need to move the capital city to Abuja was necessitated as a result of intolerable traffic, chronic housing shortages, overall congestion, overstretched infrastructure and severe environmental sanitation problems in Lagos State (Jinko, 2008).

The political transformation results in situation where several Federal Government buildings were vacated and left unused. This resulted in several abandoned Federal Government buildings in Lagos State. Similarly in berlin, (Colomb, 2012) observed that due to the political, social economic changes, a large number of abandoned buildings punctuates the city. Hence, political transformation with regards to change in capital city location has tendency to turn a vacated building abandoned.

Across the local governments in Lagos State, different Federal Government buildings are vacated and abandoned. The most significant of these buildings is the Old Federal Secretariat located in Ikoyi. The Federal Secretariat, Ikoyi which is the focus of this research is characterized by a state of decay and dilapidation due to continuous neglect by the government. In Lagos, most of such buildings can be found around Yaba, Ikoyi, Victoria Island and Marina. This is because these areas served as locations for most of the government's administrative activities during the colonial and post-colonial era. The buildings were occupied until a period during the military regime when Lagos seized to be the political capital of Nigeria. Besides creating a total dwindling effect on the values of properties within proximity, abandoned buildings usually 
turn into hideout for criminals. Most of the abandoned government buildings in Lagos are now homes to touts and hoodlums popularly known as 'area boys'. The area boys are usually perpetrators of petty and sometimes organized criminal activities in the area. (Bello, 2018) opined that Nigeria has lost $\mathrm{N} 126.2$ billion naira on abandoned Federal Government properties in Lagos. This is largely due to inability to engage in adaptive reuse of the buildings.

According to (Malgorzata, 2016), to success in any field, weaknesses must be overcome through strengths and threats must be transferred into opportunities. From this assertion, it could imply that for every building most especially public buildings to attain it potentials, the building weaknesses must be overcome and what represents the strength of the building in terms of its features and threats must be transferred into opportunities. The study conducts SWOT analysis in order to make recommendations on how to overcome identified weaknesses and threats and to maximize strengths and opportunities. This is to allow us determine the potentials and viabilities of abandoned government building using the Federal Government Secretariat at Ikoyi as a study.

To achieve the study goal, the following objectives were pursued:

- To examine the environmental and social impacts of abandoned government buildings;

- To explore potential opportunities that can be created through repossession of abandoned government buildings;

- To highlight actionable steps to restore viability, aesthetics and value to the Old Federal Secretariat, Ikoyi, Lagos.

\subsection{Literature Review}

\subsubsection{Old Federal Secretariat, Ikoyi}

The Federal Secretariat is a 15-storey high-rise building located at Ikoyi in Lagos State (Ezeh, Obioh, \&Asubiojo, 2015). The old Federal Secretariat was built in 1976. The Old Federal Secretariat consists of two buildings as a twin tower. The building served as the centre of activities of the Nigerian Federal Civil Service until 1991 when Abuja became the new political capital during the rule of Gen. Ibrahim Babangida. The building has been abandoned since the capital city of Nigeria was moved to Abuja.

\subsubsection{Abandoned Buildings}

Abandoned buildings according to (Olalusi\&Otunola, 2012) can mean an owner is ceasing to provide maintenance and operating services to a building or the loss of an owner's legal right to a building. Buildings inevitably deteriorate and may be eventually abandoned as they age, except they are maintained. The contemporary problem of abandonment is not only a continuance of an age-old dilemma. Rather, it must be recognized that this problem is now situated in the context of urban environments that have undergone substantial change over the last two or three decades.

\subsubsection{Impacts of Abandoned Buildings}

Vacant and abandoned properties, whether residential or commercial, create costly problems for cities. They reduce the quality of life, as well as economic activities around them. They are an impediment to urban development and on a larger scale, the achievement of economic development goals. Buildings may become redundant for various reasons, such as changing of economic and industrial practices, demographic shifts, increasing cost of up keeping or maintenance. Mostly because they are no longer suited for the original function and new use has not been identified.

\subsubsection{SWOT Analysis Overview}

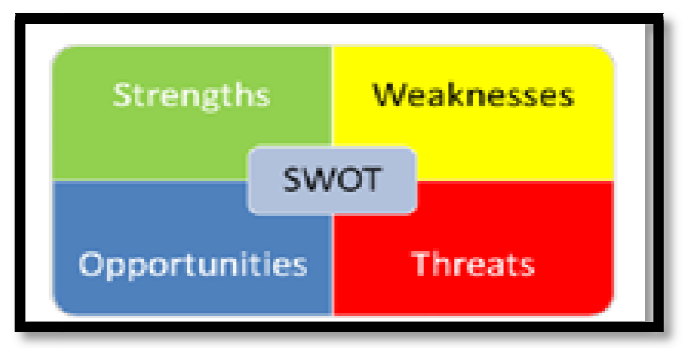

Figure 1: SWOT Analysis Framework

SWOT can be used for planning and management decisions. SWOT analysis is regarded as a powerful, organized, diagnostic and treatment tool that is used in strategic planning and management by tactfully analyzing an entity (in this case public buildings) to identify problems and find solutions to them (Morris, 2005).

\subsubsection{Harness Abandoned Building Potentials and Viabilities with Adaptive Reuse}

Adaptive reuse came into mainstream architectural parlance during the 1960's and 1970's due to the growing concern for the environment (Umar \& Said, 2019) posits that, rather than vacating and demolishing of buildings that are obsolete, it is rather more effective to leave the basic structure and fabric of the building intact then objectively change its use to suit new condition. This approach is called adaptive reuse, thereby breathing new Life into existing building, sustaining it to the next generation.

Adaptive reuse of abandoned buildings ensures that buildings are not left in reins, but reused to harness its potentials and visibilities. For example, an old factory may become an apartment building, a rundown church may find new life as a restaurant, and a restaurant may become a church (Addo, 2010). Simply put, adaptive reuse is the act of finding a 
new use for an existing building. Adaptive reuse is a phenomenon that involves stages of procedure in altering the capacity, original purpose or performance of any building work and intervenes to adjust, reuse or upgrade the living standard of a building, to suit new conditions and requirements. In addition, buildings are significant as they symbolize and give glimpses from related past periods. They should be sustained as evidence of the people's lifestyle and cultural identity instead of destroying such buildings.

\subsubsection{Adaptive Reuse Benefits}

Adaptive reuse involves converting a building to undertake a change of use required by new or existing owners (Latham, 2000). Adaptive reuse conceptual underpinning is to protect and preserve buildings. With regards to heritage buildings (Love \&Bullen, 2009) stated that it does not only retains the building but conserves the effort, skill and dedication of the original builders. In same vein, (Latham, 2000) noted that adaptive reuse also conserves the architectural, social, cultural and historical values. According to (Addo, 2010), benefits of adaptive reuse encompass environmental, social, economic and cultural benefits.

Environmental: When adaptive reuse involves historic buildings, environmental benefits are more significant, as these buildings offer so much to the landscape, identity and amenity of the communities they belong to.

- Social: The reuse of heritage buildings in established residential areas can provide the community with new housing and commercial property opportunities.

- Economic: There are several financial savings and returns to be made from adaptive reuse of historic buildings.

There are several factors that influence adaptive reuses projects, as compiled by (Sugden, 2017), these factors contribute to the success or otherwise of the project (Table 1).

\begin{tabular}{|c|c|}
\hline Influential Factor & Description \\
\hline Cultural Factors & $\begin{array}{l}\text { Factors which refer to those shared meanings associated with arts and other manifestations of human } \\
\text { intellectual achievement regarded collectively that are not, strictly speaking, historic which may } \\
\text { impact adaptive reuse, both positively and negatively. } \\
\text { - } \quad \text { Positive Impact Example: Proposed project embodies and implements a community's culture } \\
\text { and diversity within project's proposal. } \\
\text { - Negative Impact Example: Archaeological assessments that halt and or hinder process. }\end{array}$ \\
\hline Economic Factors & $\begin{array}{l}\text { Factors that may impact the outcome of adaptive reuse which stem from economic circumstances } \\
\text { pertaining to value, financing, market characteristics, investments, et c. which can affect adaptation } \\
\text { projects both positively and negatively. } \\
\quad \text { Positive Impact Example: Angel investors/Donor, Government Grants, significant return on } \\
\text { investment etc. } \\
\text { - Negative Impact Example: Poor markets, insufficient contingency funds coupled with } \\
\text { unexpected costs, undesirable Pro Forma etc. }\end{array}$ \\
\hline $\begin{array}{l}\text { Environmental } \\
\text { Factors }\end{array}$ & $\begin{array}{l}\text { Any potential effects or impacts that the existing structure, its surrounding lands, its former industrial } \\
\text { use(s), and its proposed new use(s) could have on the environment, or vice versa, which may impact } \\
\text { adaptive reuse, both positively and negatively. } \\
\text { - } \\
\text { Positive Impact Example: Government Grant for brownfield remediation. } \\
\text { - Negative Impact Example: Brownfield complications, adverse impacts to Species at Risk etc. }\end{array}$ \\
\hline Legislative Factors & $\begin{array}{l}\text { Policy direction on matters of stakeholder interest related to land use planning and development } \\
\text { which may impact adaptive reuse, both positively and negatively. } \\
\text { - } \quad \text { Positive Impact Example: promoting redevelopment } \\
\text { - } \quad \text { Negative Impact Example: Adaptive reuse not explicitly listed or encouraged through policy, } \\
\text { therefore, no specific legal backing. }\end{array}$ \\
\hline Locational Factors & $\begin{array}{l}\text { Any potential effect or impacts that stem from the location of an industrial heritage building which } \\
\text { may impact adaptive reuse, both positively and negatively. } \\
\text { - } \quad \text { Positive Impact Example: Proximity to transit, core areas, shopping, or located in } \\
\text { preferred/safe neighborhood etc. } \\
\text { - Negative Impact Example: Far from Core areas, inaccessible by public transit, dangerous } \\
\text { neighborhood, etc. }\end{array}$ \\
\hline New-Use Factors & $\begin{array}{l}\text { Any potential effects or impacts that the existing structure, its surrounding lands, its former industrial } \\
\text { use(s), and its proposed new use (s) could have on the proposed new use, or vice versa, which may } \\
\text { impact adaptive reuse, both positively and negatively. } \\
\text { - } \quad \text { Positive Impact Example: Robust and flexible building structure, proportion of new } \\
\text { construction reuse, etc. } \\
\text { - Negative Impact Example: Foundation and structure issues, incompatibility of new use, etc. }\end{array}$ \\
\hline Social Factors & $\begin{array}{l}\text { Factors or "values attached to an object, building, or place because it holds meaning for people or } \\
\text { social groups due to its age, beauty, artistry or association with a significant person or event or } \\
\text { (otherwise) contributes to processes of cultural affiliation", which may impact adaptive reuse, both } \\
\text { positively and negatively. } \\
\text { Positive Impact Example: Nostalgia, adequate consultation, community champions, etc. } \\
\text { - } \quad \text { Negative Impact Example: Tragic event within a building that creates community dislike of a } \\
\text { building or area, insufficient consultation, or bad media/political representation }\end{array}$ \\
\hline
\end{tabular}

Table 1: Influential Factors for Building Adaptive Reuse

Source: Sugden, 2017 


\section{Methodology}

The study adopts a combination of literature reviews, site visitation and quantitative approach using Linkert scale structured questionnaire. Study samples were drawn from the residents of the environment. The data required from this study include variables on socio-economic characteristics of respondents, building abandonment causal factors, environmental and social impacts of abandoned government buildings; efforts on better usage of the Old Federal Secretariat. Hence the study data were collected through questionnaire administration, physical environment assessment checklist, personal observation and physical field observation to compliment data generated from the questionnaire. The study questionnaire contains both unstructured and structured questions.

\subsection{Sampling Selection and Technique}

The study samples are occupants of buildings within the environment of the Old Federal Secretariat building, Ikoyi. The study sample is represented by the total number of residents in the study area. The units of analysis for this study are residents of the project area. The study sample frame is represented by the total of Ikoyi axis of the Old Federal Secretariat.

To determine the study sample size, ten residential streets were identified within the neighbourhood of the study location; namely, (1) Oba AdeyinkaOyekan Avenue, (2) Glover Road, (3) Oba Elegushi Road, (4) Chris Alli Crescent, (5) OlagunsoyeOyinlola Crescent, (6) DipoOrepitan Crescent, (7) HammatBalogun Close, (8) Lanre Da-Silva Close, (9) Ikorodu Crescent and (10) AgbekeRontinwa Close.

Furthermore, ten residential buildings were selected each from these streets, therefore a total of one hundred residential buildings were selected. From the selected buildings, three hundred households were selected and therefore a total of three hundred respondents were selected. Consequently, the sample size for the study is three hundred households in the study area. The study adopts systematic random sampling technique in selecting study respondents. The study data were presented and analyzed using descriptive statistical methods (frequency table). From the data presented, inferences were drawn and the implications were also explained. Data derived from the data collection instruments were synthesized with the use of Statistical Package for Social Sciences (IBM SPSS Statistics) version 22.

\section{Results}

A total of three hundred questionnaires were administered to residents within the neighbourhood of Old Federal Secretariat, Ikoyi, Lagos. From the total administered questionnaire, two hundred and ninety-one were returned valid and this was used in the data presentation.

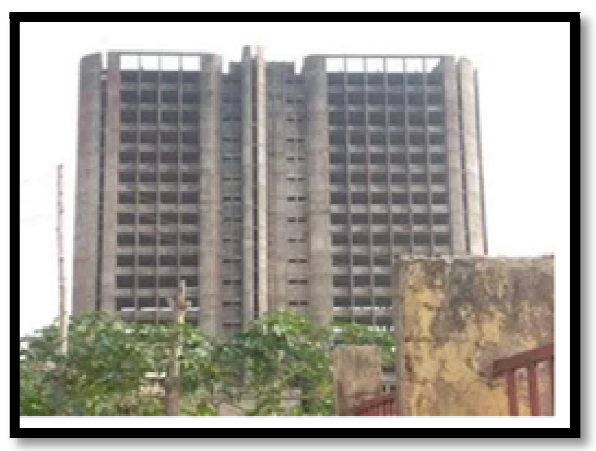

Figure 2: Old Federal Secretariat, Ikoyi

\subsection{Socio-Economic Characteristics of Residents}

\subsubsection{Age of Respondents}

The age of respondents indicate that 18-39 years are 105 936.1\%), 40-49 years are 107 (36.8\%), 50-59 years are $67(23.0 \%)$ while 60 years above are $12(4.1 \%)$ as presented in Table 4.1. This shows that the area population consists of both the young and old. It could further be inferred that the impact of the study location would be felt by residents across different age groups.

\begin{tabular}{|c|c|c|}
\hline & Frequency & Percent \\
\hline Valid 18-39yrs & 105 & 36.1 \\
40-49yrs & 107 & 36.8 \\
50-59yrs & 67 & 23.0 \\
60yrs + & 12 & 4.1 \\
Total & 291 & 100.0 \\
\hline
\end{tabular}

Table 2: Age of Respondents

Source: Author Field Survey, 2020

\subsubsection{Respondent Gender}

The gender composition shows that male respondents are 175 (60.1\%) while their female counterparts are 116 (39.95\%). In this regard, the study considers the views of both gender and would also be reflected in the study outcome. 


\begin{tabular}{|c|c|c|}
\hline & Frequency & Percent \\
\hline Valid Male & 175 & 60.1 \\
Female & 116 & 39.9 \\
& 291 & 100.0 \\
\hline
\end{tabular}

Table 3: Respondents Gender

Source: Author Field Survey, 2020

\subsubsection{Respondent Educational Status}

Basic indication of education indicates ability to write and read. Assessment of educational status on the study location indicates that sampled residents with Secondary School are 106 (36.4\%) and sampled residents with tertiary educational experience are 185 (63.6\%). Based on this it could be deduced that majority are highly educated in the study area. Furthermore, the high level of educational attainment is expected to impact positively on the study as respondents would comprehend the theme of the study.

\begin{tabular}{|c|c|c|}
\hline & Frequency & Percent \\
\hline Valid Secondary education & 106 & 36.4 \\
Tertiary education & 185 & 63.6 \\
& & \\
Total & 291 & 100.0 \\
\hline
\end{tabular}

Table 4: Respondents Educational Status

Source: Author Field Survey, 2020

\subsection{Length of Stay}

Residents sampled in the study area have stayed in the area for periods of less than 3 years, 5-10years and 11 years above, this consist of 43 (14.8\%), 131 (45.0\%) and 117 (40.2\%) respectively. This shows that sampled resident has stayed long enough to understand the dynamics of the area.

\begin{tabular}{|c|c|c|}
\hline & Frequency & Percent \\
\hline Valid Less than 3 years & 43 & 14.8 \\
5-10 years & 131 & 45.0 \\
11 years above & 117 & 40.2 \\
& & 100.0 \\
\hline
\end{tabular}

Table 5: Respondents Length of Residency

Source: Author Field Survey, 2020

\subsection{Abandoned Government Buildings Environmental and Social Impacts}

This section focused on assessment of the environmental and social impacts as results of the abandoned Old Federal Secretariat located in Ikoyi Lagos State. Different dimensions of environmental and social impacts were examined.

\subsection{Decrease in the Tempo of Economics Activities}

The impact of the abandoned Old Federal Secretariat on intensity of economic activities was examined. From the outcome, a total of $6(2.1 \%)$ and $15(5.2 \%)$ believed that the old abandoned Federal Secretariat do not have any impact on tempo of economic activities. However, a 60 (20.6\%) and 197 (67.7\%) of sampled residents opined that the old abandoned Federal Secretariat have impact on the tempo of economic activities in the area.

It could be concluded based on the views shared by sampled residents that the old abandoned Federal Secretariat do have impacts on economic activities in the area.

\begin{tabular}{|c|c|c|}
\hline & Frequency & Percent \\
\hline Valid Strongly Disagree & 6 & 2.1 \\
Disagree & 15 & 5.2 \\
Neutral & 13 & 4.5 \\
Agree & 60 & 20.6 \\
Strongly Agree & 197 & 67.7 \\
Total & 291 & 100.0 \\
\hline
\end{tabular}

Table 6: Decrease in the Tempo of Economic Activities Source: Author Field Survey, 2020

\subsection{Increase in the Rate of Vandalism and Crime in the Area}

The abandoned Old Federal Secretariat impact on the level of vandalism and crime was examined. As presented in Table 4.6, a total of $3(1.0 \%)$ and $14(4.8 \%)$ strongly disagree and disagree with regards to vandalism and crime rate. However, a total of $59(20.3 \%)$ and $(67.7 \%)$ were of the view that the abandoned Old Federal Secretariat contribute to the 
level of vandalism and crime. This implies that as the building remained abandoned, there would be more crime in the neighborhood.

\begin{tabular}{|c|c|c|}
\hline & Frequency & Percent \\
\hline Valid Strongly Disagree & 3 & 1.0 \\
Disagree & 14 & 4.8 \\
Neutral & 18 & 6.2 \\
Agree & 59 & 20.3 \\
Strongly Agree & 197 & 67.7 \\
Total & 291 & 100.0 \\
\hline
\end{tabular}

Table 7: Increase in the Rate of Vandalism \& Crime in the Area

Source: Author Field Survey, 2020

\subsection{Negative Impact on Adjoining Properties Values}

Location and situation of surroundings are impacts on the value of a given property. Sampled residents who agreed to the influence Old Federal Secretariat on the value of adjoining properties are $56(19.2 \%)$ and 167 (57.4\%). However, a total of $3(1.0 \%)$ and $27(9.3 \%)$ noted that there is impact on adjoining properties value by the abandoned Old Federal Secretariat have negative impact on adjoining properties.

\begin{tabular}{|c|c|c|}
\hline & Frequency & Percent \\
\hline Valid Strongly Disagree & 3 & 1.0 \\
Disagree & 27 & 9.3 \\
Neutral & 38 & 13.1 \\
Agree & 56 & 19.2 \\
Strongly Agree & 167 & 57.4 \\
Total & 291 & 100.0 \\
\hline
\end{tabular}

Table 8: Negative Impact on Adjoining Properties Values Source: Author Field Survey, 2020

\subsection{Increase Incidence of Blight Environment}

Blight environment incidences are functions of neglect and poor maintenance of properties. The respondents were asked to indicate if the Old Federal Secretariat could induce blight phenomenon in the area. A total of 5 (1.7\%) and $21(7.2 \%)$ do not align with this statement as they strongly disagree and disagree respectively. However, a total of 44 $(15.1 \%)$ and $210(72.2 \%)$ agree and strongly agree that the Old Federal Secretariat could trigger incidence of blight in the area. This calls for urgent attention to address the issue of the Old Federal Secretariat.

\begin{tabular}{|c|c|c|}
\hline & Frequency & Percent \\
\hline Valid Strongly Disagree & 5 & 1.7 \\
Disagree & 21 & 7.2 \\
Neutral & 11 & 3.8 \\
Agree & 44 & 15.1 \\
Strongly Agree & 210 & 72.2 \\
Total & 291 & 100.0 \\
\hline
\end{tabular}

Table 9: Increase Incidence of Blight Environment

Source: Author Field Survey, 2020

\subsection{Menace to the Environment Aesthetics}

Environmental aesthetic represents the outlook of the general environment of a given settlement. Condition of buildings or the general environment could impact the environmental aesthetic. From the responses of sampled residents in the study location, a total of $6(2.1 \%)$ and $25(8.6 \%)$ strongly disagree and disagree on the old secretariat constituting a menace to environmental aesthetics while 49 (16.8\%) and $192(66.0 \%)$ agreed and strongly agreed to the fact that the abandoned old secretariat constitute menace to environmental aesthetic.

\begin{tabular}{|c|c|c|}
\hline & Frequency & Percent \\
\hline Valid Strongly Disagree & 6 & 2.1 \\
Disagree & 25 & 8.6 \\
Neutral & 19 & 6.5 \\
Agree & 49 & 16.8 \\
Strongly Agree & 192 & 66.0 \\
Total & 291 & 100.0 \\
\hline
\end{tabular}

Table 10: Menace to the Environment Aesthetics

Source: Author Field Survey, 2020 


\subsection{Overall Impact Status}

Inaddition to the examination of individual components of environmental and social impact, the overall impact was examined. Based on the responses of the sampled residents, a total of $30(10.3 \%)$ believed that the impacts of the abandoned secretariat building are highly negative, 116 (39.3\%) opined that the impact is negative. However, a total of 46 (15.8\%), $48(16.5 \%)$ and 51 (17.5\%) opined that the impacts are moderately positive, positive and highly positive respectively. It could be inferred that the abandoned old secretariat building impact on residents is detrimental with regards to environmental and social phenomenon in the area.

\begin{tabular}{|c|c|c|}
\hline & Frequency & Percent \\
\hline Valid Highly negative & 30 & 10.3 \\
Negative & 116 & 39.9 \\
Moderately positive & 46 & 15.8 \\
Positive & 48 & 16.5 \\
Highly positive & 51 & 17.5 \\
Total & 291 & 100.0 \\
\hline
\end{tabular}

Table 11: Overall Impact Status

Source: Author Field Survey, 2020

\subsection{Old Federal Government Secretariat Building Challenges}

This section assesses the challenges of the Old Federal Government Secretariat Building. This assessment focuses on what residents perceived as hindrance to the building, why it has remained abandoned.

\subsubsection{Planning Legislations Conflicts}

Planning legislation conflicts between the Federal Government and State Government often results in challenges to several development, most especially in areas where there is no clear-cut boundary with regards to federal and state government control of development.

The respondents were asked to indicate if planning legislations conflicts represents one of the challenges to the abandoned old federal secretariat. A total of $65(22.3 \%)$ and $4(1.4 \%)$ do not agree to the statement while $56(19.2 \%)$ and $155(53.3 \%)$ align with the statement that the conflict of planning legislation is one the challenges of the abandoned secretariat.

\begin{tabular}{|c|c|c|}
\hline & Frequency & Percent \\
\hline Valid Strongly Disagree & 65 & 22.3 \\
Disagree & 4 & 1.4 \\
Neutral & 11 & 3.8 \\
Agree & 56 & 19.2 \\
Strongly Agree & 155 & 53.3 \\
Total & 291 & 100.0 \\
\hline
\end{tabular}

Table 12: Planning Legislations Conflicts

Source: Author Field Survey, 2020

\subsubsection{Political Agitation}

Sampled residents indicates that political agitation does not in any way contributes to the abandonment, this view is $8.8(302 \%)$ and $5(1.7 \%)$ sampled residents respectively. However, $123(42.3 \%)$ and 66 (22.7\%) of total resident sampled for the study claimed that one of the challenges of the abandoned secretariat is the political agitation in the country, often times federal and State Government clash of interest on the old secretariat building.

\begin{tabular}{|c|c|c|}
\hline & Frequency & Percent \\
\hline Valid Strongly Disagree & 88 & 30.2 \\
Disagree & 5 & 1.7 \\
Neutral & 9 & 3.1 \\
Agree & 123 & 42.3 \\
Strongly Agree & 66 & 22.7 \\
Total & 291 & 100.0 \\
\hline
\end{tabular}

Table 13: Political Agitation

Source: Author Field Survey, 2020

\subsubsection{Instability in Governance}

Unstable policy direction often time hinders physical development. A total of 50 (17.2\%) and 10 (3.4\%) of sampled residents claimed that instability in governance is not a challenge to the abandoned secretariat building while $121(41.6 \%)$ and 99 (34\%) agrees and strongly respectively. From the above, it could be deduced that one of the banes of the abandoned Old Federal Secretariat is the level of instability of governance and policies. 


\begin{tabular}{|c|c|c|}
\hline & Frequency & Percent \\
\hline Valid Strongly Disagree & 50 & 17.2 \\
\hline Disagree & 10 & 3.4 \\
\hline Neutral & 11 & 3.8 \\
\hline Agree & 121 & 141.6 \\
\hline Strongly Agree & 99 & 34.0 \\
\hline Total & 291 & 100.0 \\
\hline
\end{tabular}

\subsection{Old Federal Government Secretariat Building Potentials}

How can the abandoned Old Secretariat be utilized? This section focused on the opportunities available for the abandoned Old Secretariat.

\subsubsection{Old Federal Government Secretariat Building Potentials}

The usage potentials of the abandoned Old Federal Secretariat were identified as presented in Table 14 below. The identified usage potentials include Community/cultural (e.g., community centre, museum, gallery, library); Institutional (e.g., school. college, offices); Commercial (Shopping complex) and Residential apartment. Views across the study located as given by the sampled residents indicates that most residents prepared that the old federal secretariat should be put to use either as Community/cultural centre, institutional buildings, commercial complex and residential apartment. This further indicates that residents believed that usage of the building would reduce some of the identified negative environmental and social impacts of the abandoned old federal secretariat.

\begin{tabular}{|c|c|c|c|c|c|}
\hline Potentials & $\begin{array}{c}\text { Strongly } \\
\text { Disagree }\end{array}$ & Disagree & Neutral & Agree & $\begin{array}{c}\text { Strongly } \\
\text { Agree }\end{array}$ \\
\hline $\begin{array}{c}\text { Community/cultural (e.g., community } \\
\text { centre, museum, gallery, library) }\end{array}$ & $\begin{array}{c}0 \\
(0.0 \%)\end{array}$ & $\begin{array}{c}21 \\
(7.2 \%)\end{array}$ & $\begin{array}{c}5 \\
(\mathrm{I} .7 \%)\end{array}$ & $\begin{array}{c}81 \\
(27.8 \%)\end{array}$ & $\begin{array}{c}184 \\
(63.2 \%)\end{array}$ \\
\hline 1nstitutional (e.g., school, & 0 & 25 & 6 & 89 & 171 \\
\hline college, offices) & $(0.0 \%)$ & $(8.6 \%)$ & $(2.1 \%)$ & $(30.6 \%)$ & $(58.8 \%)$ \\
\hline Commercial (Shopping & 0 & 16 & 5 & 88 & 182 \\
\hline complex) & $(0.0 \%)$ & $(1.7 \%)$ & $(1.7 \%)$ & $(30.2 \%)$ & $(62.5 \%)$ \\
\hline Residential apartment & 0 & 12 & 5 & 76 & 198 \\
$(0.0 \%)$ & $(4.1 \%)$ & $(1.7 \%)$ & $(26.1 \%)$ & $(68.0 \%)$ \\
\hline
\end{tabular}

Table 15: Old Federal Government Secretariat Building Potentials Source: Author Field Survey, 2020

\subsubsection{Reuse Type}

Some of the reuse form that could be applied to the old Federal Secretariat as indicated by the sampled residents include protection 34 (1 1.7\%), transformation 62 (21.3\%), redevelopment $130(44.7 \%)$ and new construction $65(22.3 \%)$ as presented in Table 15 below. This indicates that their wide variety available to better put the abandoned secretariat building to use. However, the sampled residents favored transformation of the old federal secretariat, this view is shared by $192(66.0 \%)$ of total sampled residents. This involved the reuse of the buildings; hence it is not demolished for new buildings neither is it protected in its present form.

\begin{tabular}{|c|c|c|c|}
\hline \multicolumn{2}{|c|}{} & Frequency & Percent \\
\hline Valid & Protection & 34 & I1.7 \\
\hline & Transformation & 192 & 66.0 \\
\hline & New Construction & 65 & 22.3 \\
\hline & Total & 291 & 100.0 \\
\hline
\end{tabular}

Table 16: Reuse Type

Source: Author Field Survey, 2020

\section{Discussion}

\subsection{Actionable Steps to Revive the Old Federal Secretariat, Ikoyi, Lagos}

This section highlights actionable steps that could be taken to restore viability, aesthetic and value to the Old Federal Secretariat, Ikoyi, Lagos. The concept of adaptive reuse is adopted to revive the abandoned Old Federal Secretariat 
in Lagos state. Langston (2012) posits that, rather than vacating and demolishing of buildings that are obsolete, it is rather more effective to leave the basic structure and fabric of the building intact then objectively change its use to suit new condition. In the process of adaptive reuse for the abandoned Old Federal Secretariat, factors that should be considered include compliance with existing building codes, market opportunities for new use, stakeholder views, adaptability of the structure, environmental and social impact of the new use.

\subsection{Old Federal Secretariat Building SWOT Analysis}

The SWOT analysis as a management tool supports the decision-making process to structure information on the old Federal Secretariat abandoned building. This SWOT analysis can help to reduce potential weaknesses and threats of the Old abandoned Federal Secretariat and indicate how to maximize the strengths and opportunities.

\subsubsection{Strength}

- Location: The Old Federal Secretariat buildings have a good location. The location neighbourhood is wellestablished and serviced with easy access to other areas. The Old Federal Secretariat has good access to the full range of facilities within the immediate environment and wider area of Ikoyi.

- Available Infrastructural Facilities: The buildings have good access to wide range of infrastructure within the environment. There is good access to retail, banking, professional service facilities, and power supply among others.

The Old Federal Secretariat is situated in an area that adapt to any purpose the complex is put to. The people are well informed and will readily adopt whatever the function the Old Federal Secretariat is put to that aligns with programs and policies meant to improve and promote their social, economic and healthy living conditions

\subsubsection{Weakness}

Building Defects: Due to long abandonment of the Old Federal Secretariat, there is challenge of poor condition of the buildings. There has been little or no internal and external maintenance work, some of the external and internal features are defective. As at the time of this assessment, external features of the Old Federal Secretariat buildings are in state of disrepair.

There are some forms of structural defects in the Old Federal Secretariat building. The cost of addressing the maintenance defect of the Old Federal Secretariat could be high, which would increase the cost of reviving the Old Federal Secretariat.

\subsubsection{Opportunities}

For the abandoned Old Federal Secretariat, there are opportunities for reviving the building complex to address the case of functionally and economically obsolete. It could be upgraded and reused to increase economic viability. The site is good for redevelopment into new and modern office buildings or any other uses which are compatible with the prevailing use in the area. There are dedicated car parking facilities. There are existing set of investors ready to engage in the development of Old Federal Secretariat.

\subsubsection{Threats}

The pending physical development permits and associated issues of who have control over the approval of development of the Old Federal Secretariat between the Federal Government and Lagos State government constitute a threat to the development Old Federal Secretariat.

The current economic challenges in the country could threaten the availability of funds to engage in the development of the Old Federal Secretariat.

The developments and reuse of the Old Federal Secretariat would have a major impact on the neighbourhood. Threats to the Old Federal Secretariat also include poor land use planning in the present location which has results in incompatibility of uses.

\section{Conclusion}

The study population consists of both the young and old people. There is identified relatively high level of educational attainment among the residents and most have lived in the area for period above three years. Identified environmental and social impact of the abandoned Old Federal Secretariat include decrease in the tempo of economic activities, increasing rate of vandalism and crime, negative impact on adjoining properties values, increase incidence of blight environment and menace to the environment aesthetics. In same vein, the overall impact of the old abandoned federal secretariat was identified to be negative.

Some of the challenges that hinder the Old Federal Secretariat include planning legislations conflicts, political agitation, and instability in governance. Identified Potentials for the abandoned old federal secretariat include community/cultural (e.g., community centre, museum, gallery, library), Institutional (e.g., school, college, offices), commercial (shopping complex) and residential apartment. An adaptive use method was adopted to revive the abandoned Old Federal Secretariat. The Strength, Weakness, Opportunities and Threat to the development of Old Federal Secretariat were identified. Identified strengths include location, available infrastructural facilities and adapt to any purpose for the building. The weakness of the Old Federal Secretariat includes building defects, structural defects and cost of addressing the maintenance defect. Furthermore, the opportunities were identified these could include upgraded and reuse to increase economic viability, good for redevelopment into new and modern office buildings or any other uses, dedicated 
car parking facilities and existing set of investors while the threat to the Old Federal Secretariat are pending physical development permits and associated issues, feud between the Federal Government and Lagos State Government on development control, current economic challenges in the country could threaten the availability of funds, impact on the neighborhood and poor land use planning in the present location.

It is clear from the study that the abandoned Old Federal Secretariat buildings have negative environmental and social impact on the residents within the area. The Old Federal Secretariat should not be abandoned, but should be put to use to harness its potentials and value. The strength, weakness, opportunities and threat of the Old Federal Secretariat were examined. The building can be totally revived and transformed through adaptive reuse. Adaptive reuse when well executed would benefit different sector in the study location (lkoyi and axis).

In implementing adaptive reuse, the issue of compatibility of use to adjoining development should seriously be considered to avoid incompatibility of uses. It is expected that adoption of the study recommendations and detailed implementation of the adaptive reuse methods would restore the value of the abandoned Old Federal Secretariat.

\section{References}

i. Abdul, E.0., Raimi, K.0., \&Ibisola, A.S. (2018). Effects of Abandoned Urban Infrastructure on Environmental Development in Ogun State. Geomatics and Environmental Engineering, 12-19.

ii. Addams, L., \& Allred, A.T. (2013). The first step in proactively Managing Students' Careers: Teaching Self-SWOT Analysis. Academy of Educational Leadership Journal. 43-51.

iii. Addo, N.0. (2010). Harnessing Potential in Heritage Sites The Adaptive Reuse of Old Buildings in Old Accra. 2010: Addo, N.0 Doctoral dissertation.

iv. Bello. (2018, May 12). News Nigeria. Retrieved from https://www.today.ng/news/nigeria/nigeria-loses-nl26-2billion-abandon:https://www.today.ng/news/nigeria/nigeria-loses-n126-2-billion-abandon

v. Colomb. (2012). Pushing the urban frontier: temporary uses of space, city marketing, and the creative city discourse in 2002s Berlin. Journal of Urban Affairs, 131-152.

vi. Ezeh, G.C., Obioh, I.B.,\&Asubiojo 0.I. (20]5). Multi-elemental analysis and source apportionment of urban aerosols in a low density residential area: a case study of lkoyi Lagos Nigeria. lfe Journal of Science, 415- 427.

vii. Helms M.M., \& Nixon, J. (2010). Exploring SWOT analysis-where are we now? A review of academic research from the last decade. Journal of Strategy and Management, 215-251.

viii. Jiriko, K. (2008). Urban Master Planning in Nigeria: What Future? Kaduna: Mba Print and Publishing.

ix. Lalham, D. (2000). Creative reuse of Buildings. United Kingdom: Donhead Publishing Ltd.

x. Love, P., \&Bullen, P. (2009). Toward the sustainable adaption of existing facilities., 27(9): 357-367. Facilities, 357367.

xi. Malgorzata, J. (2016). SWOT analysis for Planned Maintenance strategy - a case study. IFAC-Papers online, 674679.

xii. Morris, D. (2005). A new tool for strategy analysis: the opportunity model. Journal of Business Strategy, 50-56.

xiii. Olalusi, 0.,\&Otunola, A.(2012). Abandonment of Building Projects in Nigeria -A Review of Causes and solutions. International Conference on Chemical, Civil and Environment engineering (ICCEE '2012) (pp. 253-255). Dubai: ICCEE' 2012.

xiv. Rostirolla, M., \&Rostirolla, P.(20 11). A Multivariate and Multicriterial Approach for the SWOT Analysis. Journal of Applied Sciences, 719-724.

xv. Schall, N.,\& Franz, J. (2014). Practitioner's Guide: Strengths, Weaknesses, Opportunities \& Threats (SWOT). Deutsche; D.G.GmbH. Ed.

xvi. Sugden, E. (2017). The Adaptive Reuse of Industrial Heritage Buildings: A Multiple-Case Studies Approach. Ontario: University of Waterloo.

xvii. Umar,S.B., \& Said, I. ('2019). Conservation Challenges of Heritage Building Reuse in Nigeria: A review of decisionmaking models. Asian Journal of Environment-Behaviour Studies, 16-36. 